\title{
The Role of Proximity in Developing an Inter-Regional Innovation System
}

\author{
Mandy Lalrindiki | ORCID: 0000-0003-1719-1707 \\ Waterford Institute of Technology, Ireland \\ mandy.lalrindiki@postgrad.wit.ie \\ Bill O'Gorman | ORCID: 0000-0002-0944-1844 \\ Centre for Enterprise Development and Regional Economy (CEDRE), \\ Waterford Institute of Technology, Waterford, Ireland
}

\begin{abstract}
While most innovation collaboration projects consist of partners who are located at close proximity, recent literature has explored the development of innovation collaboration in the context of non-spatial proximity. Using a longitudinal mixed methods design, this article explores the inter-regional collaboration of triple helix partners from four non-contiguous European regions (Bucharest-Ilfov, Romania; Central Hungary, Hungary; Castilla-La Mancha, Spain; and South East, Ireland) which worked together to develop an inter-regional innovation system. The results from the study identified three non-spatial forms of proximity (social, cognitive and organisational) that were key determinants for developing the successful inter- regional innovation collaboration studied in this research. Based on the findings derived from this research, an inter-regional innovation system framework was developed to facilitate collaboration between stakeholders based in non-contiguous regions without them having to depend on geographical proximity. The major contributions of this research to theory and practice are the development of a novel framework for inter-regional innovation systems (iRIS) which can be applied by stakeholders in regions that want to collaborate from a distance. Furthermore, the research suggests that the substitution mechanism of geographical proximity consists of not just one non-spatial form, but it consists of the three non-spatial forms identified in this research.
\end{abstract}




\section{Keywords}

collaboration - inter-regional innovation system - longitudinal study - proximity Triple Helix actors

\section{Arabic}

$$
\text { دور القرب في تطوير نظام ابتكار مشترك بين الأقاليم }
$$

Mandy Lalrindiki and Bill O'Gorman



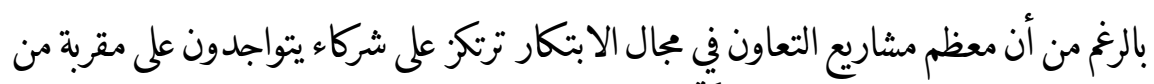



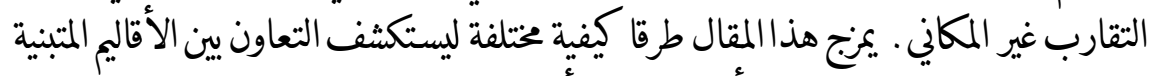

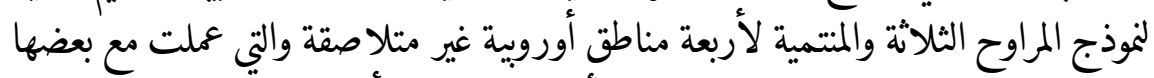



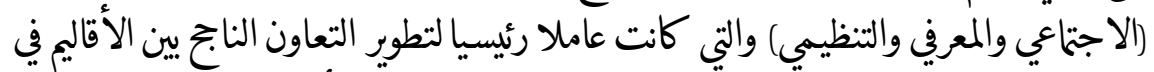

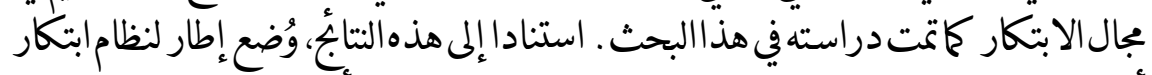

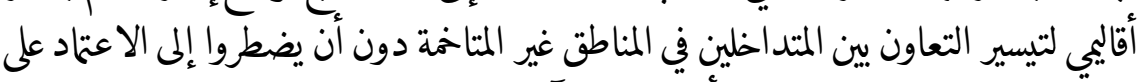

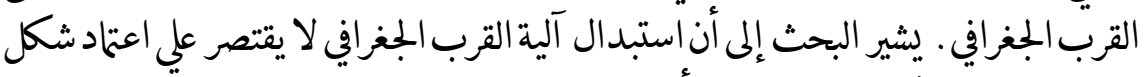

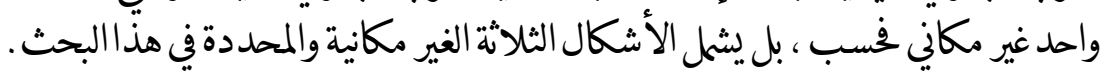

\section{الكلمات المفتاحية - (المية}

التعاون - نظام الإبتكار بين الأقايم - الدراسة الطولية - القرب - المتد اخلون حسب نموذج المراوح الثلاثة 


\title{
Chinese
}

\section{邻近性在发展跨区域创新体系中的作用}

\author{
Mandy Lalrindiki and Bill O'Gorman
}

\section{摘要}

虽然大多数创新合作项目由彼此毗邻的合作伙伴组成, 但最近的文献探讨了在空间 上非毗邻的创新合作的发展。本文使用纵向混合研究方法, 探索了来自欧洲的四个 非毗邻地区的跨区域三螺旋伙伴的合作, 和由此发展起来的跨区域创新系统。研究 结果确定了三种非空间形式的邻近性（社会、认知和组织）, 它们是本研究中的案 例成功开展跨区域创新合作的矢键决定因素。根据这项研究的结果, 我们提出了一 个跨区域间创新系统的框架, 以促进非毗邻地区的利益相矢者之间的合作, 而不必 依赖于地理邻近性。研究表明, 地理邻近的替代机制不仅包括一种非空间形式, 而 且还包括本研究发现的三种非空间形式。

关键词

合作 - 跨区域创新体系 - 纵向研究 - 邻近性 - 三螺旋活动

\section{French}

\section{Le rôle de la proximité dans le développement d'un système d'innovation interrégional}

\author{
Mandy Lalrindiki and Bill O'Gorman
}

\section{Résumé}

Alors que la plupart des projets de collaboration en innovation se composent de partenaires situés à proximité immédiate, la littérature récente a exploré le développement de la collaboration en innovation dans le contexte d'une proximité non spatiale. À l'aide d'une étude longitudinale à méthodes mixtes, cet article explore la collaboration 
interrégionale de partenaires à triple hélice de quatre régions européennes non contiguës qui ont travaillé ensemble pour développer un système d'innovation interrégional. Les résultats de l'étude ont identifié trois formes de proximité non spatiales (sociale, cognitive et organisationnelle) qui ont été des déterminants clés pour le développement de la collaboration interrégionale d'innovation réussie étudiée dans cette recherche. Sur la base des résultats issus de cette recherche, un cadre de système d'innovation interrégional a été développé pour faciliter la collaboration entre les acteurs basés dans des régions non contiguës sans qu'ils aient à dépendre de la proximité géographique. La recherche suggère que le mécanisme de substitution de la proximité géographique ne consiste pas seulement en une forme non spatiale, mais en trois formes non spatiales identifiées dans cette recherche.

\title{
Mots-clés
}

collaboration - système d'innovation interrégional - étude longitudinale - proximité acteurs de la triple hélice

\section{Portuguese}

\section{O papel da proximidade no desenvolvimento de um sistema de inovação inter-regional}

\author{
Mandy Lalrindiki and Bill O'Gorman
}

\section{Resumo}

Enquanto a maioria dos projetos de colaboração para a inovação consistem em parceiros localizados em estreita proximidade, a literatura recente tem explorado o desenvolvimento da colaboração para a inovação no contexto da proximidade não espacial. Usando um projeto de métodos mistos longitudinais, este artigo explora a colaboração inter-regional de parceiros da hélice tripla de quatro regiões europeias não contíguas que trabalharam juntas para desenvolver um sistema de inovação inter-regional. Os resultados do estudo identificaram três formas não espaciais de proximidade (social, cognitiva e organizacional) que foram determinantes-chave para o desenvolvimento da colaboração inter-regional em inovação bem-sucedida estudada nesta pesquisa. 
Com base nos resultados desta pesquisa, uma estrutura de sistema de inovação inter-regional foi desenvolvida para facilitar a colaboração entre as partes interessadas baseadas em regiões não contíguas, sem que elas dependam da proximidade geográfica. A pesquisa sugere que o mecanismo de substituição de proximidade geográfica consiste não apenas em uma forma não espacial, mas consiste nas três formas não espaciais identificadas nesta pesquisa.

\title{
Palavras-chave
}

colaboração - sistema de inovação inter-regional - estudo longitudinal proximidade - Atores Triple Helix

\section{Russian}

\section{Роль соседства в развитии межрегиональной инновационной системы}

\author{
М. Лалриндики, Б. О’Горман
}

\begin{abstract}
Аннотация
В большинстве случаев в коллективные инновационные проекты вовлечены партнеры, находящиеся поблизости друг от друга; в то же время, в недавних исследованиях было изучено развитие инновационного сотрудничества между удаленными друг от друга территориями. С использованием методов долгосрочного исследования в настоящей работе рассматриваются межрегиональные партнерства между участниками тройной спирали, находящимися в четырех европейских регионах, не граничащих между собой, но работающих вместе над развитием межрегиональной инновационной системы. Результаты анализа показали, что встречаются три пространственные формы соседства (социальная, когнитивная и организационная), которые являются определяющими в обеспечении успешного межрегионального инновационного сотрудничества, рассмотренного в данном исследовании. На основании этих выводов была разработана модель межрегиональной инновационной системы, характеризующая сотрудничество между участниками, находящимися в несоседствующих регионах, и не
\end{abstract}


зависящая от их географической близости. В исследовании выдвинуто предположение о том, что механизм географического соседства определяется не одной формой соседства, а включает в себя все три пространственные формы, идентифицированные в настоящем исследовании.

\title{
Ключевые слова
}

Сотрудничество; Межрегиональная инновационная система; Долгосрочное исследование; Соседство; Трехспиральные акторы

\section{Spanish}

\section{El papel de la proximidad en el desarrollo de un sistema de innovación interregional}

\author{
Mandy Lalrindiki and Bill O'Gorman
}

\section{Resumen}

Si bien la mayoría de los proyectos de colaboración para la innovación consisten en socios que se encuentran muy cerca, la literatura reciente ha explorado el desarrollo de la colaboración para la innovación en el contexto de la proximidad no espacial. Utilizando un diseño de métodos mixtos longitudinales, este documento explora la colaboración interregional de socios de triple hélice de cuatro regiones europeas no contiguas que trabajaron juntas para desarrollar un sistema de innovación interregional. Los resultados del estudio identificaron tres formas no espaciales de proximidad (social, cognitiva y organizacional) que fueron determinantes clave para el desarrollo de la exitosa colaboración de innovación interregional estudiada en esta investigación. Con base en los resultados derivados de esta investigación, se desarrolló un marco de sistema de innovación interregional para facilitar la colaboración entre las partes interesadas basadas en regiones no contiguas sin que tengan que depender de la proximidad geográfica. La investigación sugiere que el mecanismo de sustitución de la proximidad geográfica consiste no solo en una forma no espacial, sino que consta de las tres formas no espaciales identificadas en esta investigación. 


\section{Palabras clave}

colaboración - sistema de innovación interregional - estudio longitudinal proximidad - Actores de Triple Helix

\section{Introduction}

The great recession of 2008 spread rapidly to Europe which led to a crisis leaving millions of people unemployed; the situation necessitated Europe to develop strategies to enable an exit from the crisis (European Commission, 2010). Most member states faced more problems and fewer public resources as compared to a few member states, such as Germany and Poland, which had escaped the crisis relatively unharmed (European Commission, 2010). In order to tackle the aftermath of the crisis and to overcome short term plans, the European Union put forward three priorities to achieve a sustainable future, namely: smart, sustainable and inclusive growth; Cohesion Policy and its structural funds are key delivery mechanisms to achieve these priorities in member states and regions. The main implementation vehicle of the Cohesion Policy is the European Structural and Investment Funds (E SIFs) within which European Regional Development Fund (ERDF) monies are allocated towards regional development under different measures. The funds are built around three strands of cooperation: cross-border (Interreg A), transnational (Interreg B) and inter-regional (Interreg C). Five programming periods of Interreg have succeeded each other since 1990, Interreg $\mathrm{V}(2014-2020)$ programming period has a budget of $€ 10.1$ billion. ${ }^{1}$ Out of the total budget for the programming period, cross-border Interreg VA has a budget of $€ 6.6$ billion whereas, transnational Interreg VB has a budget of $€ 2.1$ billion and inter-regional Interreg VC has a budget of only €o.5 billion spread across four cooperation programmes. While this funding existed, the inter-regional cooperation programme is still vastly overlooked compared to that of cross-border and transnational programmes. For micro-regions to become competitive and reduce the disparity between European regions, more focus and investment toward inter-regional collaboration among less developed regions are greatly needed. The meagre attention the European Union is proffering towards inter-regional collaboration is one of the reasons that prompted the authors of this article to undertake the research to investigate the role of proximity in developing an inter-regional innovation system.

Geographical proximity has been regarded as advantageous for inter-organisational collaboration and innovation (Storper, 1997; Lawson and Lorenz, 
1999; Howells, 2002) as the possibilities of face-to-face interactions decreases coordination costs and facilitates the transfer of tacit knowledge. However, in inter-regional collaboration, transfer of tacit knowledge is often considered not to be possible from a distance. The local character and the perception of region as a locus of innovation has been emphasised in the innovation processes perceiving spatial proximity as a competitive advantage. Accordingly, certain studies (Katz, 1994; Gertler, 2003; Storper and Venables, 2004; Pan et al., 2012) have provided evidence of the advantages of being close to one another and that geographical distance can be an impediment to collaboration. On the other hand, there are numerous studies (see for example, Davenport, 2005; Malmberg and Maskell, 2006; Hansen, 2015; Garcia et al., 2018) that look at substituting geographical proximity with other forms of proximity. However, these studies have only looked at substituting one non-spatial proximity with geographical proximity. Hence, the current research addressed the dynamic interplay and interdependence of multiple non-spatial forms of proximity that enable inter-regional innovation between collaborative groups (CGs) when geographical proximity does not exist. Therefore, the purpose of this research was to investigate the role of non-spatial forms of proximity on the evolution of an inter-regional innovation system (iRIS).

This article is structured as follows: the next section introduces the theoretical underpinnings by introducing the different forms of proximity. This section also reviews substitution mechanisms for geographical proximity and current studies that address substitution mechanism as well as introducing the concept of inter-regional innovation systems and its contextual factors. The following section presents the data and methods used in this study. Thereafter, the findings are presented; followed by a discussion as to how the iRIS under study evolved. In the next section the inter-regional innovation system framework is presented. Finally, concluding the article elaborating the study's major contributions to theory and practice.

\section{Theoretical Underpinnings}

The local character and the perception of region as a locus of innovation has been emphasised in innovation processes perceiving spatial proximity as a competitive advantage which raises the question of the possibility of collaborating at a distance. However, there is also a tendency in assuming that proximity only means geographical distance (North, 1990; Scott, 2001; Gertler, 2003; Moodysson and Zukauskaite, 2014). Nevertheless, certain studies (see for example Knoben and Oerlemans, 2006; Broekel and Boschma 2012; Hansen 
2015; Fitjar et al., 2016; Garcia et al., 2018) have stressed the importance of other non-spatial proximity dimensions which are crucial for a successful innovative collaboration. Consequently, it has been broadly debated that geographical proximity can be advantageous for inter-organisational collaboration and innovation (Storper, 1997; Lawson and Lorenz, 1999; Howells, 2002) and that the possibilities of face-to-face interactions decreases coordination costs and facilitates the transfer of tacit knowledge.

\section{Different Forms of Proximity}

Proximity, often characterised by the degree of similarity of actor characteristics, refers to the degree of closeness of actors (Fitjar et al., 2016). In broad terms, it has been argued that proximity is an important factor for innovation (Knoben and Oerlemans, 2006; Broekel and Boschma, 2012; Fitjar et al., 2016; Hansen, 2015; Garcia et al., 2018) highlighting that a certain form of proximity is required for successful knowledge interactions. Boschma (2005) argued that proximity between organisations facilitates knowledge interactions via facilitating coordination and reducing uncertainty. On the other hand, too much proximity reduces the scope for novelty and can also hamper innovation (Fitjar et al., 2016). Decades of debate on proximity have emphasised the need to consider various types of proximity in addition to geographical proximity, including institutional, social, cognitive, organisational, and cultural proximity (Gertler, 2003; Zeller, 2004; Lagendijk and Oinas, 2005; Torre and Rallet 2005; Boschma 2005; Knoben and Oerlemans 2006; Lagendijk and Lorentzen 2007; Boschma and Frenken, 2009; Mattes, 2012; Balland, 2012; Paci et al., 2014; Capello and Cargaliu, 2018). A brief synopsis of these proximity dimensions is presented as follows:

Institutional proximity is understood to be economic actors sharing the same cultural habits and values (Boschma 2005). Hence, institutional proximity is regarded as an enabling factor for providing stable conditions for interactive learning to take place effectively (Boschma, 2005). However, when there is lack of strong institutions to effectively handle uncertainty, economic actors tend to rely more on trust-based relationships. According to Maskell and Malmberg (1999), information is transmitted more easily with cultural proximity and common language as a culture of shared trust, is often regarded as a capability that supports learning and innovation. Hence, institutional proximity is strongly linked with other forms of proximity. Certain studies (for example, Hansen, 2015; Lander, 2015) have explored the substitution effect between institutional proximity and geographical proximity for long distance collaboration. For instance, Hansen (2015) in his study of collaborative innovation projects in the Danish clean-tech industry suggested that there is a substitution 
effect between institutional and geographical proximity, by highlighting that the essential intermediate for this substitution effect is the existence of social proximity. Additionally, based on the study conducted on Canadian infection and immunity research networks, Lander (2015) suggested that institutional proximity can compensate for a lack of geographical proximity to support collaboration.

Social proximity refers to the strength of socially embedded relations between actors at the micro-level resulting from trust based on friendship, family relations or previous interactions (Boschma, 2005). Hence, the existence of common relationships (with friendship and trust) is supposed to diffuse informal knowledge and facilitates collaborations (Boschma and Frenken, 2009). Additionally, the reputation and trust effects created by the experience of past collaborations and repeated contacts between partners not only contributes to provide the diffusion of informal knowledge but also leads organisations with a common partner to be more likely to collaborate (Balland, 2012). For example, in an empirical study of collaborative innovation projects in the Danish clean-tech industry by Hansen (2015) highlighted the substitution effect between social and geographical proximity by expressing that longdistance collaborations are significantly more likely between partners with established social relationships.

Cognitive proximity is defined as the similarities in actors' perception, interpretation and evaluation of new ideas or the degree of overlap in actors' knowledge-base (Knoben and Oerlemans, 2006). For actors to efficiently and effectively communicate and transfer knowledge, a common frame of reference (such as organisational culture, customs, norms and routines) is required as it influences the way actors see and know the world (Knoben and Oerlemans, 2006). According to Boschma (2005), cognitive proximity in terms of a shared knowledge-base is required for actors to communicate, understand, absorb and process new information successfully. While acknowledging in theory, that a combination of geographical proximity and some level of cognitive proximity is sufficient for interactive learning to happen, Boschma (2005) also highlighted that geographical proximity alone is unlikely to enhance interactive learning and innovation and, therefore, suggested that cognitive proximity is a prerequisite for learning to happen. In an empirical study by Paci et al. (2014) that analysed a sample of 276 European regions within the prevailing knowledge production function (KPF) framework for the complementary role of proximity dimensions in enhancing innovation diffusion, found that a common cognitive base is a crucial element for conveying knowledge across regions. Similarly, a study by Capello and Caragliu (2018) on interrelations between different forms of proximity found that when spatial distance 
increases, regions need to be cognitively and technologically close for collaboration to happen.

Organisational proximity is defined as the degree to which organisations have similar routines and incentive mechanisms (Metcalfe, 1994). Boschma (2005) defined organisational proximity "as the extent to which relations are shared in an organisational arrangement, either within or between organisations" (2005: 65). Accordingly, organisational proximity can be considered as "the set of routines, explicit or implicit, which allows coordination without having to define beforehand how to do so" (Rallet and Torre, 1999: 375). The degree of hierarchy in intra or inter-organisational arrangements impacts the ability of organisations to coordinate their economic activity and avoid uncertainty and opportunism (Hansen, 2015).

Even though all these aspects of proximity refer to "being close to something measured on a certain dimension", they are clearly not identical. For instance, various dimensions of proximity have been defined in earlier literature (Hussler, 2004; Boschma, 2005; Knoben and Oerlemans, 2006) in terms of similarity of knowledge bases (cognitive proximity), shared cultural backgrounds such as language and religion (cultural proximity), similarity of formal rules and informal constraints (institutional proximity), similarity of organisational contexts (organisational proximity), personal trust-based relationships (social proximity) and shared technological experiences (technological proximity) while geographical proximity refers to the physical/spatial closeness. Literature on proximity recognises different types of proximities, because just being geographically close on its own, does not automatically lead to intensive cooperation networks or high levels of innovative outputs (Koschatzky, 200o; Trippl, 2012).

In their study of a dyadic level of dimensions of proximity highlighting this multi-level embeddedness, Knoben and Oerlemans (2006) stressed the importance of organisational proximity for inter-organisational collaboration (IOC). The reason behind stressing the importance of organisational proximity is that IOcs are more efficient and lead to better results when the organisational context of both interacting partners is similar since this similarity facilitates mutual understanding. This form of proximity is seen as a prerequisite for dyadic and collective learning and the basis for the co-creation of new resources and innovation (Kirat and Lung, 1999). As well as organisational proximity, other studies (see for example Moulaert and Sekia, 2003; Hansen, 2015) have also debated the advantages of geographical proximity for interorganisational collaboration and innovation as the possibilities of face-to-face interactions decreases coordination costs and facilitates the transfer of tacit knowledge (Storper, 1997; Lawson and Lorenz, 1999; Howells, 2002). However, 
even in the current fourth industrial revolution (Industry 4.0), in inter-regional collaboration, where regions are not contiguous, the transfer of tacit knowledge is hugely problematic. This is because, tacit knowledge is embedded in the person rather than the document and the use of traditional modes of communication such as ICT tools to send files are not appropriate or conducive for transferring tacit knowledge (Castaneda and Toulson, 2021). The covid19 pandemic has highlighted a generation of high quality, interactive video conferencing tools. While these tools can indirectly enhance existing tacit knowledge sharing processes, they still do not directly enable tacit knowledge sharing (Mastrom, 2013). It was this problematic transfer of tacit knowledge between people collaborating across non-continuous regions that prompted the need to perform this research into exploring the possibility of substituting spatial proximity with forms of non-spatial proximity.

\section{Substitution Mechanism: Non-Spatial Forms of Proximity Substitutes for Geographical Proximity}

In his critical assessment of proximity and innovation, Boschma (2005) stressed the possibility of substituting non-spatial forms of proximity with geographical proximity while still acknowledging the indirect effect geography has through the facilitation of non-spatial forms of proximity and noted that "geographical proximity per se is neither a necessary nor a sufficient condition for learning to take place" (2005: 62). Consequently, Malmberg and Maskell's (2006) essay on localised learning which looked at the existence of benefits of spatial proximity in processes of interactive learning, acknowledged that collaboration between actors does not necessarily require geographical proximity but it does have an indirect impact on "developing a common institutional, social and cultural setting" (2006: 9).

The substitution mechanism of geographical proximity with non-spatial forms of proximity was analysed by Hansen (2015) in his empirical study on the relationships between geographical and non-spatial proximity dimensions on collaborative innovation projects. In that study, the author conducted structured interviews with representatives from Danish cleantech firms $(n=50)$ where the main theme of the interviews was the firms' product development projects with external partners, which were most recently completed. Hansen (2015) found that there was no indication of substitution mechanism between geographical and institutional proximity. However, upon further analysing the data qualitatively, Hansen (2015) found that it is indeed possible to substitute institutional proximity with geographical proximity. He posited that while the substitution mechanism exists, it is of relatively low importance in the relationship between the geographical and institutional dimensions, which supports 
the suggestion of Gertler (2003) that the main challenge of long-distance collaborations is to overcome institutional differences.

While Boschma (2005) stressed the possibility of substituting non-spatial forms of proximity for geographical proximity, he also stated that (in theory) geographical proximity combined with some level of cognitive proximity is sufficient for interactive learning. However, in the case of inter-regional collaboration where regions are not in close proximity, it is unclear from literature which forms of non-spatial proximity or/and combination of these are required for interactive learning and innovation. For instance, Davenport (2005) investigated the SME knowledge acquisition processes and critical interfaces of innovative SME s in a study of 15 firms in New Zealand to determine if organisational or geographic proximity (or both) are the key to knowledge-acquisition. The study found that the key knowledge interfaces are with entities that are neither resident in the region, nor in New Zealand, therefore, organisational proximity dominates knowledge-acquisition activity over geographic proximity. On the other hand, in a study of 4,337 collaborations between university-industry collaboration in Brazil, Garcia et al (2018) provided empirical evidence that cognitive proximity is a substitute for geographical proximity because shared capabilities and expertise between a university and a collaborating firm stimulates long distance collaboration. These studies, therefore, identified one nonspatial form of proximity (for example: cognitive proximity or organisational proximity) as a substitute for geographical proximity but no evidence of combining these different non-spatial proximities existed. The current research, therefore, addresses the lack of knowledge pertaining to proximity substitution by highlighting the dynamic interplay and interdependence of non-spatial proximities when geographical proximity does not exist.

\section{Inter-Regional Innovation System}

The concept of innovation systems was initially applied at the national level (Lundvall, 1992; Nelson, 1993; Niosi et al., 1993; OECD, 1999). The national system of innovation (NSI) literature reveals huge differences between countries as regards attributes such as economic structure, $R \& D$ base, institutional setup, and innovation performance (Edquist, 2001). The NSI was developed with the aim to understand the comparative differences in technological development profiles and specialisation between different countries. In the late 199os other determinations of innovation systems emerged. For example, authors such as Carlsson and Stankiewicz (1991); Carlsson and Jacobsson (1994); and Carlsson and Jacobsson (1997) proposed "technological systems" and suggested that systemic interrelationships are unique to technology fields. While other 
authors emphasised the importance of a sectoral approach and examined how groups of firms develop and manufacture products as well as how they generate and utilise the technologies of that sector (see for example Breschi and Malerba, 1997; Mowery and Nelson, 1999; Malerba, 2002), a growing interest in regional innovation systems (RIS) also emerged (see Braczyk et al., 1998; Autio, 1998; Howells, 1999; Acs, 200o; Mytelka, 200o; Doloreux, 2002; Bathelt and Depner, 2003; Fornahl and Brenner, 2003). Although it is not denied that national, technological, and sectoral factors are essential, it is also convincingly argued that the regional dimension is of key importance because that knowledge spillovers, which play a key role in the innovation process, are often spatially bounded (Audretsch and Feldman, 1996; Anselin et al., 1997; Bottazzi and Peri, 2003). The RIS approach highlights the regional dimension of the production and the exploitation of new knowledge, thereby helping to explain regional differences in innovation capacity and economic strength.

On the other hand, RIS theory has also been applied to cross-border interaction, collaboration and innovation. Whereby, cross-border regions (СвRs) are defined as geographic areas consisting of neighboring territories belonging to different nation states with political- administrative borders as well as economic and relational borders (Perkmann, 2003; Weidenfeld, 2013). Fundamentally, a strongly integrated cross-border regional innovation system (CBRIS) can emerge if (i) the cross-border regions host an advanced scientific base and a well-developed innovation related infrastructure, (ii) industries on both sides of the border are innovative, (iii) economic relations exist and there are processes of collective learning across the border, (iv) certain levels of socio-cultural and institutional proximity exist in the border regions and (v) the absorptive capacity of the regions is such as to make autonomous decisions to carry out policies (Trippl, 2010; Makkonen and Rohde, 2016). As well as these dimensions, СвRIS require a certain degree of geographical proximity (Lundquist and Trippl, 2013). It is also considered that the contiguous crossborder regions are most relevant for developing joint, or at least coordinated, regional policies (OECD, 2013) as such regions have geographic proximity and may be a more favourable environment for the development of a shared vision. Which in many cases may be supported by greater cultural proximity than in macro-regions that group many countries together. While being geographically close could potentially facilitate cooperation, it does not necessarily result in high levels of knowledge transfer as certain relational proximities need to also exist in order to complement their physical proximity. In the case of inter-regional innovation system (iRIS), inter-regions are defined as regions that do not share physical borders with neighboring territories belonging to 
different nation states with political-administrative borders. Hence, iRIS is defined as an innovation system wherein regions collaborate from a distance with other non-contiguous regions with certain levels of relational proximities to substitute the absence of their physical proximity. While a significant amount of research has been performed in relation to cross-border regional innovation system, there is little to no research on inter-regional innovation system. Therefore, this research explored the development of an inter-regional innovation system between four regions that do not share contiguous borders (Bucharest-Ilfov, Romania; Central Hungary, Hungary; Castilla-La Mancha, Spain; and South East, Ireland).

A successful regional innovation system (RIS) is dependent of the existence of collaborative interactions and cooperation between the Triple Helix $(\mathrm{TH})$ actors based in that region. The definition of an RIS as a set of interacting knowledge generation ${ }^{2}$ and exploitation ${ }^{3}$ subsystems (Cooke, 2004) stems from Porter's work on clusters; where a geographically proximate group of interconnected firms can produce competitive advantage based on the exploitation of unique resources and competencies, which must be reproduced and developed through continuous innovation (Porter, 1990, 2000). This definition of RIS underlines the dynamic characteristic of competitive advantage leading to innovation, which represents the high road to economic development. This is a more systematic approach to developing the endogenous capacity of firms and regions to innovate and focuses on the role of knowledge creation, absorption and diffusion (Asheim et al., 2005). This puts stronger focus on the actors, agencies and governance forms relevant for constructing regional advantage in a Triple Helix model that builds on the idea of university-industry-government interactions that contributes to regional and national wealth creation through increased innovation and venture creation (Etzkowitz and Leyesdorff, 2000). The Triple Helix (тн) concept has grown into an analytical framework (Ranga and Etzkowitz, 2013) for exploring the complex dynamics of the knowledge society and for informing policymakers at national, regional and international level in the design of new innovation and development strategies. In this framework, innovation is seen as the result of interactions within and between University, Industry, Government institutional spheres, with university shifting from a secondary to a primary institutional sphere and an equal partner to Industry and Government, and at times taking a lead role in implementing innovation (Ranga, 2012).

The main thesis of the тн model (Etzkowitz and Leydesdorff, 1995, 1997) is that the interactions between University, Industry and Government are optimal conditions for innovation. The TH model posits these three spheres, 
overlapping and interacting freely, with each "taking the role of the other" (Etzkowitz, 2008: 9), producing hybrid organisations such as science parks, spin-offs, university-run enterprises, and incubators from these interactions.

The current research investigates the actors, specifically $\mathrm{TH}$ actors, which are collaborating both at the regional and inter-regional level. It must be reiterated here, that while inter-regional collaboration explores non-contiguous regions that do not share borders, the advantages that cross-border regions have regarding geographical proximity, therefore, are non-existent in the current research scenario. However, barriers with cross-border collaboration can also be expected at the inter-regional level, especially because of the absence of geographical proximity. For example, van den Broek and Smulders (2014) stated that the nation state border itself can act as a barrier to cross-border learning by hindering interaction between actors on both sides of the border. For instance, the different institutional settings of university versus industry versus government actors can be a hurdle for interactions (Etzkowitz and Leydesdorff, 2000) especially when regions collaborate with different institutions across borders. This is even more so across non-contiguous borders as relevant norms and beliefs alter as well as the rules and regulations under which they interact. Because the $\mathrm{TH}$ is interrelated with the concept of institutional interactions, it is necessary to consider institutional gaps.

\section{Institutional Gaps in Inter-Regional Innovation System}

Institutions provide (temporary) stability by governing and conditioning social life by reducing uncertainty in everyday practice (North, 1990; Scott, 2001; Gertler, 2003). Institutions might consist of rules, routines, habits, conventions, customs or practices that are internalised by the majority of actors in a population (Gertler, 2003; Moodysson and Zukauskaite, 2012; Moodysson and Zukauskaite, 2012). When institutions collaborate, they may facilitate processes of collective learning and the build-up of economic relations by providing (temporary) stability (van den Broek and Smulders 2014) but the multi-level collaboration can also impede this build-up of regularities and structure. Institutions may help to explain why cooperation among actors in a cross-border setting can be problematic due to divergent laws, regulations, norms and values (Makkonen et al., 2017). Although there is an inclination to assume that institutions facilitate interaction in RIS, van den Broek and Smulders (2014) argued that in a cross-border RIs, institutions' influence on actors on both sides of the border could also create institutional gaps thereby hindering cross-border cooperation. Based on these premises, the current research conceptualises that institutional gaps occur in inter-regional innovation systems. Therefore, 
using Scott's (2001) work as a basis of analysis, the gaps were categorised into three pillars: regulative, normative and cultural-cognitive. Regulative gaps refer to the barriers of cooperating among actors resulting from formal institutions such as rules and regulations. On the other hand, normative and culturalcognitive gaps refer to the gaps that can occur due to the limited knowledge of the values, norms and cultures. sThese institutional gaps can arise in crossborder and inter-regional collaboration as stakeholders from different regions are embedded in different national and regional institutional structures which could hinder the evolution of inter-regional innovation systems. While institutions provide rules of the game, they do not provide actors with clear answers on how to act (Beckert, 1999), thus if the institutions conflict, actors may fall into institutional gaps (van den Broek and Smulders, 2014).

While the dynamics of proximities are an important issue, they have not been sufficiently addressed (Balland et al., 2015). Accordingly, the current research addresses the lack of the dynamics of proximity by highlighting the dynamic interplay and interdependence of non-spatial proximities without geographical proximity at play. Even though regional innovation systems and cross-border regional innovation systems have been extensively studied in literature, inter-regional innovation systems are heavily overlooked. Therefore, the purpose of this research was to investigate the role of non-spatial forms of proximity on the evolution of an inter-regional innovation system (iRIS).

The next section presents the methodological consideration and the approach employed to conduct this research.

\section{Methods and Data Gathering}

In order to investigate the process of collaboration between regional $\mathrm{TH}$ actors at an inter-regional level and to understand how proximity or non-proximity influences the evolution of inter-regional innovation systems, it was necessary to identify and work with an emerging or existing inter-regional innovation system. Therefore, this research employed a purposive sampling technique. Whereas it is relatively easy to identify inter-regional collaborative groups through EU funded platforms such as HORIZON 2020, INTERREG, and ERASMUS (to mention a few). However, if a researcher is not a member or employee of one of the participating organisations, it is extremely difficult to get access to these collaborative groups and even more difficult to engage with such groups in an immersive longitudinal way. If access is granted to a researcher, it will be still extremely difficult for that researcher the immerse themselves in the collaborative consortium, and even more difficult to get 


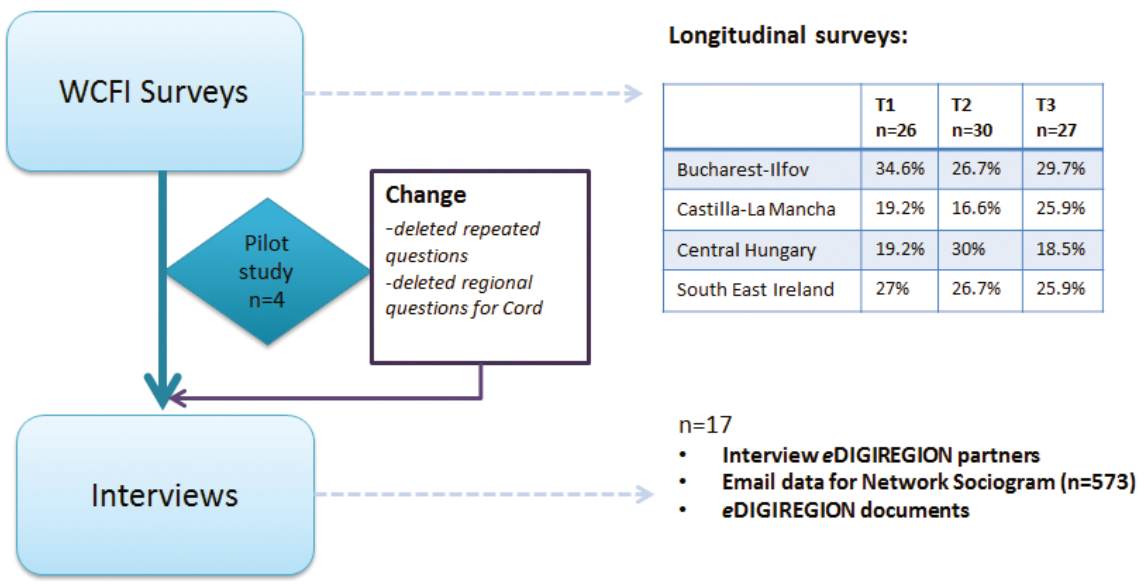

FIGURE 1 Data collection flow chart

access to relevant project documentation and even more difficult still to understand and appreciate the nuances at play between the collaborating partners. Therefore, four regions (Bucharest-Ilfov, Romania; Central Hungary, Hungary; Castilla-La Mancha, Spain; and South East region, Ireland) collaborating in a European Commission funded project called $e$ DIGIREGION, ${ }^{4}$ were used as a convenient sample for this study. $e$ DIGIREGION was a unique collaborative project involving fifteen (15) Triple Helix partners from four European noncontiguous regions. The $e$ DIGIREGION project was a research-in-action with all four regions fully involved in the inter-regional collaboration.

In order to capture the complex interactive nature of the actors involved in the inter-regional collaboration process, this research employed a mixed methods research approach. The data collection was conducted at a multistep, multi-phased level (see Figure 1) wherein an explanatory sequential mixed methods approach was employed.

At the inter-regional level, a survey was conducted with the $e$ DIGIREGION collaborating partners at three different time-points. In these surveys, the Wilder Collaboration Factors Inventory (WCFI) Survey (Mattessich et al., 2001) was administered in order to understand the actors' perceptions of their collaboration process and the longitudinal data allowed the researchers to explore the changes in these perceptions. After an extensive review of successful collaborations and the influential factors involved, Mattessich et al. (2001) of the Wilder Research Centre identified 20 factors (see Table 1 ) that influence the success of organisational collaborations. Based on this data, they developed the Wilder Collaboration Factors Inventory (WCFI) as an instrument to understand the perception of the actors about their collaboration process. All 


\section{WCFI factors}

1. History of Collaboration or cooperation in the community

2. Collaborative group seen as a legitimate leader in the community

3. Favorable political and social climate

4. Mutual respect, understanding, and trust

5. Appropriate cross section of members

6. Members see collaboration as in their self-interest

7. Ability to compromise

8. Members share a stake in both outcome and process

9. Multiple layers of participation

10. Flexibility

11. Development of clear roles and policy guidelines

12. Adaptability

13. Appropriate pace of development

14. Open and frequent communication

15. Established informal relationships and communication links

16. Concrete, attainable goals and objectives

17. Shared vision

18. Unique purpose

19. Sufficient funds, staff, material, and time

20. Skilled leadership

(SOURCE: ADAPTED FROM MATTESSICH ET AL., 2001)

factors have been tested in multiple studies and are deemed generalisable by the researchers (Mattessich et al., 2001). After conducting the research, the Wilder Research Centre created a questionnaire ${ }^{5}$ designed to test the 20 factors, with 40 Likert-scale style questions that investigate the details of the organisations' actions related to collaboration and partnership. The WCFI score helped in assessing the strengths and weaknesses of their collaborative activities. However, as regards the current research, rather than taking steps to address the weaknesses in the $e$ DIGIREGION collaborative activity at every time point, the researchers administered the survey without intervention in order to identify the natural changes of each actor's perception of the collaborative process over time. Consequently, the nature of the data collected allowed testing for changes of the different factors at different points of time. 
The analyses of the longitudinal survey provided an overview of the interregional institutional interactions, allowing it to be used in the framing of the qualitative interview phase of the research process (see Figure 1). The interview process established greater in-depth understanding of the collaboration among stakeholders at an inter-regional level and the challenges this entails when geographical proximity is not existing. These interviews $(\mathrm{N}=17)$ helped to interpret the quantitative findings derived from the surveys and provided insights into the actors' views about changes in perception if they occurred over the course of their collaboration process. The findings from both the quantitative and qualitative phase were then interpreted by triangulating the data from both regional and inter-regional level.

\section{Findings}

This section of the article presents the main findings from the two phases of this research. Firstly, findings from the three-time points survey are presented which is followed by the findings from the interview phase.

\section{Survey Findings}

A longitudinal survey was conducted at three (3) time points using the Wilders Collaboration Factors Inventory (WCFI) tool. This tool was developed and validated by the Wilder Research Centre which identified 20 factors that influence successful collaborations. These factors have been tested in multiple studies and are deemed generalisable by the researchers (Mattessich et al., 2001). Since it has been stated that the partners in the Collaborative Group (CG) were collaborating from a distance, the aim of the survey questionnaires was not to enquire about geographical proximity, but rather to establish if the CG had a successful collaboration and how this collaboration evolved. The surveys were administered in $e$ DIGIREGION partner meetings which were held in a different region each time (see Table 2). This changing from region to region could explain the variations in the number of respondents for each survey, because all the partners could not travel to all meetings. ${ }^{6}$ Since the survey was administered at different points in time throughout the collaboration process, in order to capture the uniformity in the perception at a particular time point, partners who were not present at these meetings were not followed up to respond to the WCFI survey.

Each region is represented by $\mathrm{TH}$ organisations (see Table 2) viz., Higher Education Institute (HEI), Industry (IND) and Government (GOV) 
TABLE 2 Descriptive Statistics-Respondents' regions and organisations

\begin{tabular}{lccc}
\hline Time point & T1 & T2 & T3 \\
\hline $\begin{array}{l}\text { Location where survey was } \\
\text { administered }\end{array}$ & $\begin{array}{l}\text { Bucharest, } \\
\text { Romania }\end{array}$ & $\begin{array}{l}\text { Albacete, } \\
\text { Spain }\end{array}$ & $\begin{array}{l}\text { Waterford, } \\
\text { Ireland }\end{array}$ \\
Data collection month & May 2016 & Nov 2016 & Mar 2017 \\
Number of respondents & 26 & 30 & 27 \\
Regions & & & \\
Central Hungary South East Ireland & $19.2 \%$ & $30.0 \%$ & $18.5 \%$ \\
Bucharest-Ilfov Castilla-La Mancha & $27.0 \%$ & $26.7 \%$ & $25.9 \%$ \\
& $34.6 \%$ & $26.7 \%$ & $29.7 \%$ \\
& $19.2 \%$ & $16.6 \%$ & $25.9 \%$ \\
Total & $100 \%$ & $100 \%$ & $100 \%$ \\
Organisation type & & & \\
Higher Education Institutions (HEI) & $34.62 \%$ & $43.33 \%$ & $33.33 \%$ \\
Government Representatives (GOV) & $46.15 \%$ & $26.67 \%$ & $37.04 \%$ \\
Industry (IND) & $19.23 \%$ & $30 \%$ & $29.63 \%$ \\
Total & $100 \%$ & $100 \%$ & $100 \%$ \\
\hline
\end{tabular}

Representatives. In the first time point ( $\mathrm{T} 1)$, Gov represented $46.15 \%$ of the total respondents followed by HEI and IND with $34.62 \%$ and $19.23 \%$ respectively. However, in the second time point (T2), HEI represented $43.33 \%$ of the total respondents followed by IND and G OV with $30.00 \%$ and $26.67 \%$ respectively. While in the third time point $\left(\mathrm{T}_{3}\right)$, Gov represented $37.04 \%$ of the total respondents followed by HEI and IND and with $33.3 \%$ and $29.63 \%$ respectively (see Table 2). From the three time points, it can be noted that the participation of IND increased as the collaboration progressed. The GOV participation declined in the second time point ( $\mathrm{T} 2)$ whereas, HEI increased in time point $(\mathrm{T} 2)$. The differences in the mix of respondents may have a bearing on the collaborative group's (CG) perception of the collaboration at each time point.

The longitudinal approach provides for a better understanding of the collaborative group (CG) as the collaboration progresses and also provides data for testing changes in the respondents' perceptions from one time point to another. According to WCFI, scores of 1.0 to 2.9 are of concern, which should be addressed, however, all the factor scores in the CG reached the threshold above 3.0 in all the three time points. Even though scores between 3 and 3.9 ought to prompt discussion by the CG to determine if the CG needs to devote 
attention to the factors, it does not mean it is of great concern or the CG is not working effectively. However, as mentioned earlier, in order to capture the natural progression of the collaboration process, no intervention was made. Figure 2 highlights the factors at the three time points. Even though some factors (Factors 6, 7, 9, 12, 13, 18, 19) did not increase in value, the majority of the factors did increase in value and the calculated factor averages shows that the CG was working efficiently.

Overall, the findings from WCFI suggested that the CG was working from the beginning ( $\mathrm{T} 1)$ despite the fact that the perception of regions and organisations differ. The CG continued to collaborate effectively despite their differences throughout their collaborative process. The findings above present the descriptive statistics of survey respondents and Likert Scale variables on the factors scores. Even though the factors scores imply that this CG was working effectively, the differences among group means and their variations among and between groups were further analysed with the help of ANOVA.

After running a one-way ANOVA test on all the 20 factors to establish the significant differences for three time points, 8 Factors (see Table 3) varied by the respondents' region. In T1, Factor 3 (Favourable political and social climate) shows a statistical significance between the Central Hungary, Hungary and South East region, Ireland. This means that the perception about the support (or at least do not oppose) from the political leaders and the general public regarding the collaborative group is relatively lower among actors representing the Central Hungary, Hungary than that of the actors representing South

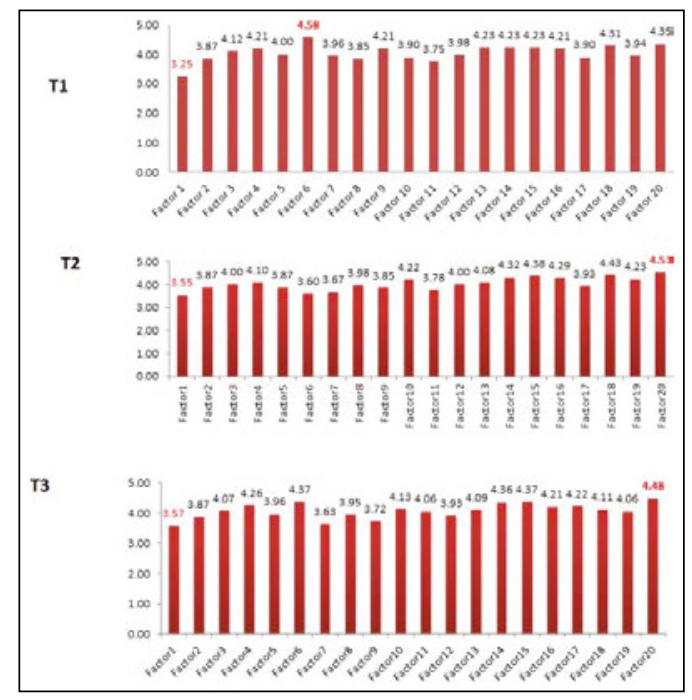

FIGURE 2

Factors scores in three time points (SOURCE: CURRENT RESEARCH) 
TABLE 3 Tukey HSD by respondent's region for three time points

\begin{tabular}{|c|c|c|c|c|c|}
\hline $\begin{array}{l}\text { Dependent } \\
\text { Variable }\end{array}$ & $\begin{array}{l}\text { (I) } \\
\text { Respondent's } \\
\text { region }\end{array}$ & $\begin{array}{l}(\mathrm{J}) \\
\text { Respondent's } \\
\text { region }\end{array}$ & $\begin{array}{l}\text { Mean } \\
\text { difference } \\
(\mathrm{I}-\mathrm{J})\end{array}$ & $\begin{array}{l}\text { Std. } \\
\text { error }\end{array}$ & Sig. \\
\hline \multicolumn{6}{|l|}{ T1 } \\
\hline $\begin{array}{l}\text { Factor } 3 \\
\text { (Favourable } \\
\text { political and } \\
\text { social climate) }\end{array}$ & $\begin{array}{l}\text { Central } \\
\text { Hungary } \\
\text { Hungary }\end{array}$ & $\begin{array}{l}\text { South East } \\
\text { Ireland }\end{array}$ & $-1.31429^{*}$ & 0.35421 & 0.006 \\
\hline T2 & & & & & \\
\hline $\begin{array}{l}\text { Factor } 3 \\
\text { (Favourable } \\
\text { political and }\end{array}$ & $\begin{array}{l}\text { Central } \\
\text { Hungary } \\
\text { Hungary }\end{array}$ & $\begin{array}{l}\text { South East } \\
\text { Ireland }\end{array}$ & $-1.24306^{*}$ & 0.28365 & 0.001 \\
\hline social climate) & $\begin{array}{l}\text { Castilla } \\
\text { La Mancha } \\
\text { Spain }\end{array}$ & $\begin{array}{l}\text { South East } \\
\text { Ireland }\end{array}$ & $-1.0875^{\circ *}$ & 0.33279 & 0.015 \\
\hline $\begin{array}{l}\text { Factor } 4 \\
\text { (Mutual respect, } \\
\text { understanding, } \\
\text { and trust) }\end{array}$ & $\begin{array}{l}\text { Central } \\
\text { Hungary } \\
\text { Hungary }\end{array}$ & $\begin{array}{l}\text { Bucharest } \\
\text { Ilfov Romania }\end{array}$ & $-.75000^{*}$ & 0.26985 & 0.046 \\
\hline $\begin{array}{l}\text { Factor } 5 \\
\text { (Appropriate } \\
\text { cross section }\end{array}$ & $\begin{array}{l}\text { Central } \\
\text { Hungary } \\
\text { Hungary }\end{array}$ & $\begin{array}{l}\text { South East } \\
\text { Ireland }\end{array}$ & $-.75694^{*}$ & 0.26288 & 0.037 \\
\hline of members) & $\begin{array}{l}\text { Castilla La } \\
\text { Mancha Spain }\end{array}$ & $\begin{array}{l}\text { South East } \\
\text { Ireland }\end{array}$ & $-.91250^{*}$ & 0.30842 & 0.031 \\
\hline $\begin{array}{l}\text { Factor } 9 \\
\text { (Multiple layers }\end{array}$ & $\begin{array}{l}\text { Castilla La } \\
\text { Mancha Spain }\end{array}$ & $\begin{array}{l}\text { South East } \\
\text { Ireland }\end{array}$ & $-1.1625^{\circ *}$ & 0.34357 & 0.011 \\
\hline of participation) & $\begin{array}{l}\text { Castilla La } \\
\text { Mancha Spain }\end{array}$ & $\begin{array}{l}\text { Bucharest } \\
\text { Ilfov Romania }\end{array}$ & $-1.41250^{*}$ & 0.34357 & 0.002 \\
\hline $\begin{array}{l}\text { Factor } 16 \\
\text { (Concrete, } \\
\text { attainable goals }\end{array}$ & $\begin{array}{l}\text { Central } \\
\text { Hungary } \\
\text { Hungary }\end{array}$ & $\begin{array}{l}\text { South East } \\
\text { Ireland }\end{array}$ & $-.73611^{*}$ & 0.20184 & o.oo6 \\
\hline and objectives) & & $\begin{array}{l}\text { Bucharest } \\
\text { Ilfov Romania }\end{array}$ & $-.69444^{*}$ & 0.20184 & 0.01 \\
\hline
\end{tabular}


TABLE 3 Tukey HSD by respondent's region for three time points (cont.)

\begin{tabular}{|c|c|c|c|c|c|}
\hline $\begin{array}{l}\text { Dependent } \\
\text { Variable }\end{array}$ & $\begin{array}{l}\text { (I) } \\
\text { Respondent's } \\
\text { region }\end{array}$ & $\begin{array}{l}(\mathrm{J}) \\
\text { Respondent's } \\
\text { region }\end{array}$ & $\begin{array}{l}\text { Mean } \\
\text { difference } \\
(\mathrm{I}-\mathrm{J})\end{array}$ & $\begin{array}{l}\text { Std. } \\
\text { error }\end{array}$ & Sig. \\
\hline \multicolumn{6}{|l|}{$\mathrm{T}_{3}$} \\
\hline $\begin{array}{l}\text { Factor } 16 \\
\text { (Concrete, attainable }\end{array}$ & $\begin{array}{l}\text { Castilla La } \\
\text { Mancha Spain }\end{array}$ & $\begin{array}{l}\text { South East } \\
\text { Ireland }\end{array}$ & $-.76190^{*}$ & 0.23794 & 0.019 \\
\hline goals and objectives) & $\begin{array}{l}\text { Castilla La } \\
\text { Mancha Spain }\end{array}$ & $\begin{array}{l}\text { Bucharest } \\
\text { Ilfov Romania }\end{array}$ & $-.69643^{*}$ & 0.23038 & 0.029 \\
\hline $\begin{array}{l}\text { Factor } 18 \\
\text { (Unique purpose) }\end{array}$ & $\begin{array}{l}\text { Castilla La } \\
\text { Mancha } \\
\text { Spain }\end{array}$ & $\begin{array}{l}\text { South East } \\
\text { Ireland }\end{array}$ & $-1.07143^{*}$ & 0.33604 & 0.020 \\
\hline
\end{tabular}

East Ireland. In other words, the actors representing Central Hungry perceived that they had little support from the general public and their regional leaders which significantly differed from that of South East Ireland. Whilst there are 5 Factors that show statistical significance among the regions in $\mathrm{T}_{2}$, there are 2 factors that are statistically significant in $\mathrm{T}_{3}$. The analysis based on respondent's region and the WCFI factors highlighted that though the inter-regional collaboration was working effectively, there are still differences in perception regarding the $\mathrm{CG}$.

Additionally, the one-way ANOVA test was performed on all the 20 factors to establish the significant differences for three time points by the respondents' organisations (see Table 4). None of the factors in T1 has statistically significant differences among the $\mathrm{TH}$ organisations. However, in $\mathrm{T} 2$, three factors (Factor 11, Factor 12 and Factor 14) have statistically significant difference among the organisations. Finally, in $\mathrm{T}_{3}$, Factor 8 and Factor 11 show a statistical significance between Higher Education Institutions (HEI) and Government Representatives (GOV). The analysis based on respondents' organisations and the WCFI factors underlined that there are differences in perception regarding the CG not only based on the regions they represented but also by the organisations they represent.

\section{Interview Findings}

The inter-regional institutional framework examined in this research consists of actors in different regional $\mathrm{TH}$ institutions that do not share contiguous 
TABLE 4 Tukey HSD by respondent's organisation for three time points

\begin{tabular}{|c|c|c|c|c|c|}
\hline Dependent variable & $\begin{array}{l}\text { (I) } \\
\text { Respondent's } \\
\text { organisation }\end{array}$ & $\begin{array}{l}(\mathrm{J}) \\
\text { Respondent's } \\
\text { organisation }\end{array}$ & $\begin{array}{l}\text { Mean } \\
\text { difference } \\
(\mathrm{I}-\mathrm{J})\end{array}$ & $\begin{array}{l}\text { Std. } \\
\text { error }\end{array}$ & Sig. \\
\hline \multicolumn{6}{|l|}{ T2 } \\
\hline $\begin{array}{l}\text { Factor } 11 \\
\text { (Development of } \\
\text { clear roles and policy } \\
\text { guidelines) }\end{array}$ & HEI & GOV & $-1.20673^{*}$ & $0.335^{23}$ & 0.004 \\
\hline $\begin{array}{l}\text { Factor } 12 \\
\text { (Adaptability) }\end{array}$ & HEI & IND & $-.65812^{*}$ & 0.23892 & 0.027 \\
\hline $\begin{array}{l}\text { Factor } 14 \\
\text { (Open and frequent } \\
\text { communication) }\end{array}$ & HEI & GOV & $-.65705^{*}$ & 0.23322 & 0.024 \\
\hline $\mathrm{T}_{3}$ & & & & & \\
\hline $\begin{array}{l}\text { Factor } 8 \\
\text { (Members share a stake } \\
\text { in both process and } \\
\text { outcome) }\end{array}$ & HEI & GOV & $-1.10000^{*}$ & 0.29156 & 0.003 \\
\hline $\begin{array}{l}\text { Factor } 11 \\
\text { (Development of } \\
\text { clear roles and policy } \\
\text { guidelines) }\end{array}$ & HEI & GOV & $-.73889^{*}$ & 0.25483 & 0.021 \\
\hline
\end{tabular}

borders and are in a CG to develop an inter-regional innovation system (iRIS). The findings suggest that inter-regional institutions involved in the $e$ DIGIREGION project established an interaction and collaboration that works effectively over a distance even though there were differences in their perception. This, contrary to conventional wisdom is evident from the research that geographical proximity is not an optimal condition for an inter-regional innovation system as the CG worked effectively without the existence of geographical proximity.

However, in order to better understand how this inter-regional collaboration was working and also to have an in-depth understanding of the influence their difference in perceptions has on their collaboration; interviews were administered with seventeen (17) triple helix partners from the $e$ DIGIREGION project (see Figure 3 for the structure of interview participants). 




FIGURE 3 Representatives of the CG for interview process on the inter-regional level

Figure 3 shows the dyadic multi-level approach of the interview phase of this research, which enabled the authors to have an in-depth understanding of the CG from the perspectives of different levels of roles in the CG. In order to understand if the inter-regional collaboration process developed within the CG was sustainable over time, the interviews were conducted one year after the $e$ DIGIREGION project ended which adds robustness to the findings. The set of questions were different for the three levels of partners in the project structure (see Figure 3). Gathering the perspectives of the coordinator and regional leads regarding their roles was important in order to understand the workings of the collaboration from the management level. The set of questions for the Coordinator included questions regarding the coordinator's role and the challenges encountered while coordinating the innovation collaboration. The Regional Leads questionnaire included questions relating to their role and the challenges they encountered as a regional lead, their respective regional focus and Inter-regional collaboration focus. Finally, the TH representatives' questionnaire included questions, which had a regional and inter-regional focus. All three sets of questions aligned with the Wilders Collaboration Factor Inventory (WCFI) questions in order to derive a deeper understanding of what makes inter-regional and inter-institutional collaboration work.

According to the analysis, the distance between the regions, which were in the CG, did not have a negative impact on the inter-regional collaboration. In fact, all of the key informants agreed that distance did not hinder the collaboration, moreover, it was pointed out that it was the nature of European projects to have partners that are not geographically close to each other. The G OV representative of the Central Hungary, Hungary described how the distance did not have an impact on the collaboration in the following way: "The distance did not have an impact nor was it a problem because we have to work with people 
who we are actually close with regards distance, but we still have to drive to get there. So whether you are sitting in a car, train or airplane, anywhere in Europe is reachable so I don't think the distance affected anything."

Another dimension that was discovered during the analysis was that the relationship between the project partners, which helped the collaboration, along with the use of technology, that regular communication was possible even when project partners were not in close proximity. However, the temporary proximity that did exist throughout the collaboration process needs to be highlighted here, because the project partners met physically at least once a year for project team meetings and conferences. All of which contributed to developing the informal and formal relationships that were established through meeting in person.

While the quantitative analysis identified that representatives from GOV thought there was regular interaction and communication chain to convey necessary information to one another, representatives from HEI believed otherwise (see $\mathrm{T}_{2}$ findings). The difference in perception regarding open and frequent communication among the collaborating organisations was an important finding to investigate further. Therefore, this was followed up in more detail during the face-to-face interviews. In overall terms though, the findings indicate that the communication between partners was open and also frequent. For example, $29 \%$ of the key informants expressed that the communication was more frequent when they were involved in specific tasks; while the remainder of the interviewees thought that the communication became better as the collaboration process continued. The analysis characterised the informants' perception of the coordinator's communication and management style. For example, the HEI representative from Bucharest Ilfov, Romania stated: "I can tell you that I was very pleased with the professional coordination honestly. The coordinator is very able to coordinate an activity, looking very closely to all the things related to the project. So, I was very pleased about his management and dedication to the project."

The current research, therefore, suggests that institutional gaps (such as regulative, cultural-cognitive and normative) existed in the inter-regional collaboration. However, these institutional gaps did not hinder the development of the $e$ DIGIREGION inter-regional innovation system. The findings clearly identified that there were differences not only in organisational culture but also differences in their countries' cultures, which was sometimes a difficulty when trying to make decisions. For example, the Gov representative from the Central Hungary, Hungary stated that: "being exposed to these differences [cultural and organisational] was a positive definitely because good practices 
were passed on. But on the negative side, sometimes it was difficult to move along with some decisions because of the different cultures."

However, the findings also implied that these differences are common when working on European projects, as such projects usually require collaborating with people from different regions, more often than not with non-contiguous borders. Although these differences could hinder the workings of not only cross-border but also inter-regional collaboration, the current research suggests that the differences provided a positive learning experience where good practices were shared and in turn built a good informal and learning network. One of the interviewees also regarded the success of the collaboration in terms of the positive learning experience that was gained from the collaboration; the IND representative from Castilla La Mancha stated: "I think the success of the collaboration is the way you look at it. Personally, it was a learning experience and a positive one so this also makes you improve your own skills in terms of collaboration because you learn from it". On the other hand, formal institutional gaps (regulative gaps) were also highlighted in the findings where there were differences in the rules and regulation of each institution. While it is harder to induce formal institutional change (van den Broek and Smulders, 2014), the differences, not only in how policies are implemented or decisions are made in each institution, were regarded by the collaborative group (CG) as a gained valuable experience by being exposed to the different working styles in the CG. For example, the HEI representative from Castilla La Mancha stated:

In the CG we had to deal with different kinds of institutions. For example, we are dealing with more bureaucratic institutions like universities, so they cannot really make all their decisions by themselves as they have their own structure and then we also have smaller companies where the hierarchy most probably is flexible so decision-making is easier. Perhaps for the coordinating partner, it could be a little challenging but it was quite an experience to deal with different working styles.

The analysis also revealed differences such as culture, organisational and work culture. However, these differences did not hinder the collaboration, because all interviewees felt it was a good opportunity to learn from each other and share knowledge not only regarding the project but the workings of each other's region and organisation.

Although the findings suggest differences in the regional institutional frameworks, they also acknowledge that as inter-regional collaboration progressed, the institutions involved got to know each other much better (creating both 
formal and informal relationship) therefore; these differences did not negatively impact on making their collaboration work. On the other hand, the differences in the rules and regulations of each institution were also highlighted (from a more bureaucratic institution like universities to the more flexible hierarchy of smaller companies where decision-making is easier). However, all interviewees emphasised the positive experience and the learning that they gained as a result of being exposed to the different working styles in the CG.

Overall, different institutional gaps existed in the CG, which however, did not hinder the evolution of an inter-regional innovation system. In fact, 2.5 years after the completion of the $e$ DIGIREGION project, many of the CG partners were still collaborating on various project proposals for EU funding and also on the $e$ DIGIREGION project's six (6) inter-regional joint action plans (iJAPs).

The overall objective of the interview process was to understand what makes inter-regional collaboration work. The resultant analysis suggests that there are three main themes (proximities) which make inter-regional collaboration work effectively over a distance. Table 5 presents these three themes. Details of each theme are presented after Table 5 .

TABLE 5 Three key themes for inter-regional collaboration

$\begin{array}{lll}\text { Themes } & \text { Definition } & \text { Findings }\end{array}$

Openness to

learn and share

(cognitive

proximity)

Informal

relationships

(social proximity)
Cognitive proximity is

defined as the similarities in actors' perceptions, interpretations and evaluations of new ideas or the degree of overlap in actors' knowledge-base (Knoben and Oerlemans, 2006

Social Proximity is defined in terms of the relationships between actors that are socially embedded when they involve trust based on friendship, kinship and experience (Boschma, 2005)
When good formal and informal relationships are established, trust is built among the CG which supported the development of a cognitive understanding of other partners involved.

The informal relationships were also considered helpful in order to strengthen the ties between the partners in the CG. Which led to the sharing of knowledge not only about the project but also beyond the scope of the project. 
TABLE 5 Three key themes for inter-regional collaboration (cont.)

\begin{tabular}{|c|c|c|}
\hline Themes & Definition & Findings \\
\hline $\begin{array}{l}\text { Leadership and } \\
\text { management } \\
\text { (organisational } \\
\text { proximity). }\end{array}$ & $\begin{array}{l}\text { Knowledge creation depends } \\
\text { on a capacity to coordinate } \\
\text { the exchange of complemen- } \\
\text { tary pieces of knowledge } \\
\text { owned by a variety of actors } \\
\text { within and between organ- } \\
\text { isations (Boschma 2005: 64). }\end{array}$ & $\begin{array}{l}\text { The current research showed } \\
\text { that good coordination } \\
\text { management and leader- } \\
\text { ship played a vital role in the } \\
\text { success of the inter-regional } \\
\text { collaboration. }\end{array}$ \\
\hline
\end{tabular}

\section{Discussion}

This section of the article discusses the findings in relation to the proximities that emerged as being substitutes for geographical proximity in the interregional collaborative processes studied.

\section{Openness to Learn and Share (Cognitive Proximity)}

Knowledge creation and innovation are often cumulative, and this accumulation relies on the capacity to learn (Garcia et al., 2018). However, effective transfer of knowledge requires absorptive capacity to identify, interpret and exploit new knowledge (Nooteboom 2000; Boschma 2005). Hence, cognitive proximity is commonly defined as the similarities in actors' perceptions, interpretations and evaluations of new ideas or the degree of overlap in actors' knowledge-base (Knoben and Oerlemans, 2006). Boschma (2005) considered cognitive proximity as a prerequisite for an interactive learning process to take place and other scholars (such as Paci et al., 2014; Capello and Cargliu 2018) have claimed that cognitive proximity can substitute geographical proximity because of the existence of similar capabilities and common channels of communication which can stimulate interaction over a long distance. While the current study supports Boschma's (2005) claim that cognitive proximity is a prerequisite, it does not prove that cognitive proximity alone contributed to the success of an inter-regional collaboration. Based on the findings of the current research, social and organisational proximity along with cognitive proximity played a vital role in making the inter-regional collaboration work, especially in the absence of geographical proximity. When good formal and 
informal relationships are established, trust is built among the CG which supports the development of a cognitive understanding of other partners involved in a collaborative process. Additionally, a CG without good management and leadership may not be as successful or efficient even if there is an existence of good social and cognitive proximity. Hence, the three forms of proximity (social, cognitive and organisational) contribute to the success of an interregional collaboration. Hansen (2015) attested that cognitive proximity can substitute geographical proximity in long distance collaboration but however he did not explore the overlap between other forms of proximity in substituting geographical proximity.

The current research suggests that cognitive proximity is one of the key determinants for an inter-regional collaboration, but research did not find any suggestions that cognitive proximity alone contributed to the success of long distance collaboration. While it posits that cognitive proximity is developed through a certain degree of social proximity, different attributes contributed to developing cognitive proximity especially when different kinds of institutions from different regions are involved in such collaboration. The similarities in actors' perceptions, interpretations and the openness to learning and sharing of knowledge were developed through different partners:

(i) having a history of collaboration,

(ii) similar motivation to achieve the objectives

(iii) valued the uniqueness of the collaboration,

(iv) frequent communication, and

(v) building mutual respect and trust overtime.

All these attributes played a vital role in developing a cognitive proximity which evolved over time with the existence of a close informal relationship.

\section{Informal Relationships (Social Proximity)}

Previous research indicates that economic relations are to some extent always embedded in a social context (Polanyi, 1944; Granovetter, 1985), which in turn affect economic outcomes (Boschma, 2005). Furthermore, it is also suggested that the more socially embedded the relationships are the more interactive the learning is and the better the innovative performance. Accordingly, the current research also showed that one of the most important determinants of interregional innovation collaboration was the social proximity within the CG. The interviews during the qualitative phase of this research highlighted the importance of establishing informal links within the CG as it was considered essential and helpful for the collaboration in order to increase the trust among the $\mathrm{CG}$, as it enabled the interaction environment to be more comfortable and friendly. As the regional leader for South East Ireland stated, 
I think at the end of the day when you strip everything away, it comes down to human interactions and human relationships on a social level, so I think the partners got on extremely well from that point of view and again that was very much down to the fact that that there were physical meetings at least twice a year. So people became more comfortable on a personal level and that helped in the progress of the project.

The informal relationship was also considered helpful in order to strengthen the ties between the partners in the CG and the sharing of knowledge not only about the project but also beyond the scope of the project. In order to appreciate to extent to which the inter-regional collaboration process was effective within the CG and to establish how sustainable the process was over time, the interviews were conducted one year after the $e$ DIGIREGION project ended. What was found was that the partners were still collaborating with each other on different project proposals. Therefore, informal relationships that were formed during the collaboration process were regarded as a critical part of the success of the collaboration. Thus, the research findings support existing literature that informal relationships can diffuse informal knowledge and facilitate collaborations (Boschma and Frenken, 2009) where the reputation and trust effects created by the experience of past collaborations and repeated contacts between partners makes them more likely to collaborate (Balland, 2012).

While it has been argued that too much social proximity may weaken the learning capability of organisations (Boschma, 2005), the current research suggests that the better the social proximity, the more likely collaboration will succeed. Because the more the partners in the CG got to know each other, they interacted more comfortably with each other which also led to continued collaboration even after the project ended. For example, the regional leader for Castilla La Mancha, Spain stated that "I think the possibility to continue collaborating with the partners even after the end of the project is one of the aspects that worked well in the collaboration. We have learned a lot and we are still willing to learn more. I think our region is still far from developing what other regions are already establishing. So, I think this is very important for our region to have the possibility to collaborate again."

\section{Leadership and Management (Organisational Proximity)}

Knoben and Oerlemans (2006) stressed the importance of organisational proximity for inter-organisational collaboration (IOC). The reason behind stressing the importance of organisational proximity is that IOC s are more efficient and lead to better results when the organisational context of the interacting partners are similar as it facilitates mutual understanding. Organisational 
proximity is defined as the degree to which organisations have similar routines and incentive mechanisms (Metcalfe 1994). Therefore, the current research followed this definition of organisational proximity keeping in mind that "knowledge creation also depends on a capacity to coordinate the exchange of complementary pieces of knowledge owned by a variety of actors within and between organisations" (Boschma, 2005: 64). The current research showed that good coordination management and leadership played a critical role in the success of the inter- regional collaboration. The CG established a good formal and informal relationship among the partners involved which also helped in building trust and mutual understanding especially when different kinds of institutions were involved in the collaboration process. However, no collaboration is ideal hence, certain circumstance arise which are unforeseen. Thus, a capacity of the leadership to manage effectively is vital in order to achieve results from the CG. The research findings indicate that the partners involved in the collaboration considered the management by the leadership and the structure of the collaboration process as being effective in achieving the success of their inter-regional collaboration. This effectiveness is attributed to the capability of the leadership to efficiently coordinate thereby creating a participation structure and defined tasks which were put together by the leaders of the project (executive team).

The results from the current research suggest that even when cultural and institutional proximity did not influence the development of an inter-regional collaboration, cognitive, and social proximity played a vital role in the process. Hence, stating that when organisational proximity influences collaboration, all four dimensions of proximity (as proposed by Knoben and Oerlemans, 20o6) do not necessarily influence the evolution of an inter-regional innovation system.

\section{Developing a Framework for Inter-Regional Innovation System (iRIS)}

The current research established that inter-regional collaboration can happen even without geographical proximity, contrary to the popular notion that geographical distance can be an impediment to collaboration. While regional institutional frameworks were taken into consideration, the differences in the four regional institutional frameworks did not hinder the evolution of the inter-regional innovation system (iRIS) studied, despite the institutional gaps. Hence, the current research suggests the key determinants for making an inter-regional collaboration work. The three main dimensions viz., social, 


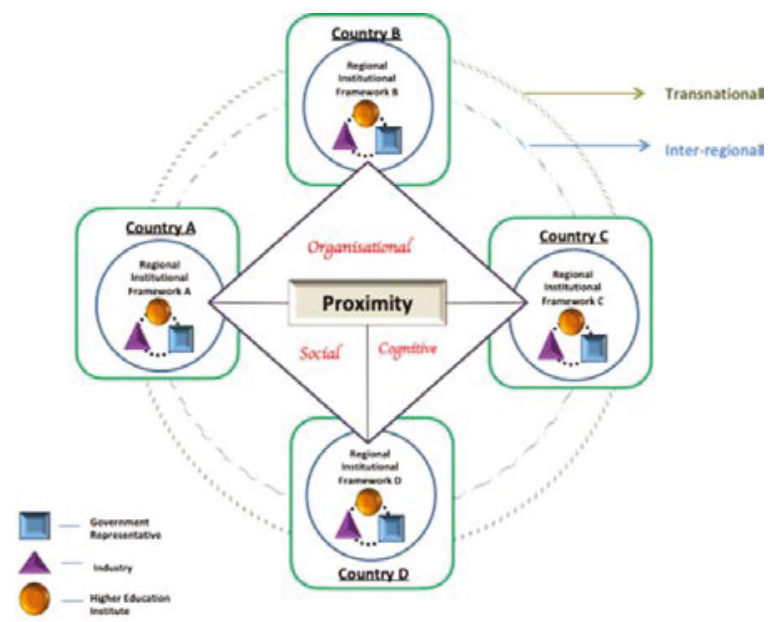

FIGURE 4 Inter-regional innovation system framework

cognitive and organisational proximity played a vital role in establishing the inter-regional innovation system especially without the existence of geographical proximity. Even though the regional institutional frameworks in the current research did not hinder the development of the iRIS, they should still be taken into consideration when developing an iRIS, because different regional institutional frameworks could vastly differ from each other which could hinder the development of iRIS.

Based on the findings of the current research, a framework for inter-regional innovation system is proposed in Figure 4.

Figure 4 illustrates a framework for an inter-regional innovation system (iRIS) which shows four different regional institutional frameworks $(\mathrm{A}, \mathrm{B}, \mathrm{C}$ and D) which are within each country (A, B, C and D). It visualises geographical distances with no two regions sharing borders nor are they in close proximity. The iRIS framework also highlights the three main forms of proximity (namely, cognitive, social and organisational) as integral to developing an inter- regional collaboration. Based on the $e$ DIGIREGION Inter-regional Innovation System (iRIS), the current research postulates that the key ingredients to develop a successful inter-regional innovation system are:

\section{Regional Institutional Framework}

Understanding regional institutional frameworks is critical in order to develop a successful iRIS. The collaboration among Triple Helix (тH) institutions (Academia, Government representatives and Industry) accommodates both institutional and individual roles in innovation, and explore the complex 
dynamics of a knowledge society and inform policy-makers at national, regional and international levels in the design of new innovation and development strategies. While the institutional framework holds the formal and informal rules, the organisational set where actors (such as the $\mathrm{TH}$ ) interrelate in order to achieve specific goals, establish policies and procedures (UNEP, 2006). But it can also hinder collaboration on an inter- regional level. For example, the system of government affects policy making for regions. Regions with a centralised form of government have polices made by the central ministries with little or no influence from the regional government, thereby affecting the policy making and effective collaboration on an inter-regional level. Though the differences in institutional frameworks and the non-existence of $\mathrm{TH}$ collaboration in the CG did not influence the success of the iRIS, it is well worth noting that no two regional institutional frameworks will be the same. Thereby, its influence at an inter-regional level could also vary.

\section{Institutional Gaps in Inter-Regional Collaboration}

As stated, the difference in regional institutional frameworks could influence the iRIS, which could also develop institutional gaps (such as culturalcognitive, normative and regulative) that could affect the evolution of an iRIS. Regulative gaps refer to the barriers of cooperating among actors resulting from formal institutions such as rules and regulations. On the other hand, normative and cultural-cognitive gaps refer to the gaps that can occur due to the limited knowledge of the values, norms and cultures (van den Broek and Smulders, 2014). While institutions provide rules of the game, they do not provide actors with clear answers on how to act (Beckert, 1999), thus if the institutions conflict, actors may fall into institutional gaps (van den Broek and Smulders, 2014). Different institutional gaps did exist in this study's iRIS; however, they did not hinder the development of a successful iRIS. It is important to realise that institutional gaps do exist because they could hinder the creation and development of an iRIS; on the other hand, institutions can overcome these gaps and develop a successful iRIS.

\section{Temporary Geographical Proximity}

Because regions collaborating at an inter-regional level are not close to each other and do not share borders, the advantages of being close to one another such as the sharing of tacit knowledge and low cost of coordination does not exist. Therefore, temporary geographical proximity through physical meetings and meeting at conferences are vital in establishing a successful inter-regional collaboration. 


\section{Critical Dimensions for Successful iRIS}

The most important determinants for establishing an iRIS are social, cognitive and organisational proximity. These three determinants are the critical dimensions for a successful iRIS. According to this study's iRIS where geographical proximity did not exist, the iRIS was developed because these three proximities existed. Cognitive proximity is developed through a certain degree of social proximity. The similarities in actors' perceptions, interpretations, and their openness to learn and share knowledge were developed through establishing informal relationships, different partners having a history of collaboration, similar motivation to achieve the objectives and valued uniqueness of the collaboration, frequent communication and building mutual respect and trust overtime. Good coordination management and leadership also played an essential role in the success of the inter- regional collaboration. The effectiveness of leadership contributes to the development of a clearly defined participation structure and tasks, which is necessary for managing a consortium with different institutions to achieve a successful iRIS.

While a framework for innovation systems has been extensively studied in literature, inter- regional innovation systems are heavily overlooked. Needless to say, the perception of region as a locus of innovation has been emphasised in the innovation processes perceiving geographical proximity as a competitive advantage, which does not exist in the case of inter-regional innovation systems. However, innovation system studies have been explored mainly conceptually while empirically, cross-border regional innovation systems (CBRIS) have been approached precisely through single industry sector case studies (Makkonen and Rohde, 2016). These sectors range from manufacturing and business service sectors (Koschatzky, 2000; Lundquist and Winther, 2006) to bio- and clean-technology (Coenen et al., 2004; Hansen, 2013; Kiryushin et al., 2013) and low-tech fields of horticulture (van den Broek and Smulders, 2014). The analysis and discussion in these studies has commonly included the TH type of cross border collaboration which has been included in the empirical literature on CBRIS. In their review of the CBRIs literature, Makkonen and Rohde (2016) examined and highlighted the mismatch between the conceptual and empirical studies. One of the difficulties in applying the concept of CBRIS in empirical literature, according to these researchers, is the fuzziness in the varying definitions of proximity. Hence, in order to effectively test and integrate in literature, different types of proximity should also be defined in a way it can also be empirically studied. While the dynamics of proximities are an important issue, it has not been sufficiently addressed (Balland, 2015). Accordingly, the current research addressed the lack of the dynamics 
of proximity by highlighting the dynamic interplay and interdependence of the three non-spatial forms of proximity that enable the inter-regional innovation between the CG. While other studies (see for example Davenport, 2005; Malmberg and Maskell, 2006; Hansen, 2015; Garcia et al., 2018) have explored the role of non-spatial proximity in substituting geographical proximity for collaboration and knowledge transfer, these studies have only looked at one nonspatial proximity with geographical proximity. However, the current research contributed to this area of literature by providing the evidence of the interplay between three different forms of non-spatial proximity in order to develop an inter-regional innovation system (iRIS). While the current research contributed to the empirical study of iRIS, it is important to note that the Collaborative Group (CG) studied may not be representative of all inter-regional collaborative partnerships and therefore the findings are not generalisable.

\section{Conclusion and Contributions}

The focus of this article was on the dynamic actor-centric collaborative group (CG) which comprised of different Triple Helix (TH) institutional actors from different European regions and their influence on developing an inter-regional innovation system (iRIS) without the existence of geographical proximity. Since the advantages that cross-border RIS has (for example, contiguous region, geographical proximity, transfer of tacit knowledge) is not existing in an inter-regional collaboration, this article also examined the possibility of substituting geographical proximity with other forms of proximity for a successful inter- regional innovation system.

By proposing a new framework for inter-regional innovation collaboration, this article contributes to both theory and practice. Firstly, this research contributes to theory by substituting geographical proximity with other forms of proximity. While geographical proximity has been regarded as being advantageous for innovative collaboration to happen, this research provided evidence for the possibility of collaborating over a distance and establishing a successful inter-regional innovation system (iRIS) by using different forms of proximity in an integrated way. Therefore, this research adds to the argument of a substitution mechanism for geographical proximity with other forms of proximity. Although previous empirical research (Hansen, 2015) explored substitution mechanism, this particular research explored the overlap between other forms of proximity (namely, social, cognitive and organisational) in substituting geographical proximity. Furthermore, the current research also challenged the notion that too much proximity can be detrimental to learning and innovation as the evidence shows that the more the social proximity increased, cognitive 
proximity also increases which was a critical determinant for the success of the iRIS.

Additional to the contribution to theory is the development of a novel framework for inter- regional innovation system (iRIS) which can be applied to regions that want to collaborate from a distance. The framework (presented in Figure 4) describes key determinants (namely, the existence of social, cognitive and organisation proximity) in developing an iRIS where geographical proximity does not exist. Thus, it provides a more comprehensive theoretical view of developing an inter-regional collaboration network from a distance. While contributing to theory, the iRIS framework can be expanded as the research provided a methodology for developing the iRIS framework which can be implemented by regions and different institutions that want to establish an effective inter-regional collaboration.

Finally, a number of recommendations for future research emerged from this study. Firstly, the current research was conducted on one inter-regional collaborative group; therefore, the findings are not deemed generalisable. A suggestion for future research, therefore, is to conduct the same research on more than one CG at the same time, with both contiguous and non- contiguous regions. Secondly, based on the regional differences which were highlighted by the stakeholders it would be valuable to understand the effect (if any) of the CG on each region. Therefore, future research should involve interviews with the CG members to establish if the learning and experience gained from the CG has an impact on institutional frameworks in their respective regions. Finally, this research indicated that the regional institutional frameworks did not hinder the collaboration at the inter-regional level. However, the characteristics of different institutional frameworks may vary over time (and situational circumstance, such as political, economic, or environmental changes may also have an impact) which could in turn hinder the collaboration process at an inter-regional level. Therefore, conducting this research again over a longer time period may yield different results. Such research and results would yield a more robust but flexible, adaptive and sustainable framework for the development of iRIS.

\section{Endnotes}

1. See: http://ec.europa.eu/regional_policy/en/policy/cooperation/european -territorial/.

2. These consist of public and private research laboratories, universities and colleges, technology transfer agencies, vocational training organisations.

3. Understood as the regional production structure. 
4. The project, $e$ DIGIREGION: Realising The Digital Agenda Through Transnational Cooperation, was funded as part of an $\mathrm{FP}_{7}$ Regions of Knowledge Programme specifically "Transnational cooperation between regional research-driven clusters".

5. The questionnaire and a complete explanation of its structure and use can be found at www.wilder.org.

6. It was not a contractual requirement that all consortium partners attend all meetings. Therefore, attendance was of people's own free will. Consequently, their attendance did not add bias to the research or its analysis.

\section{References}

Acs ZJ (ed.) (200o) Regional Innovation, Knowledge, and Global change. London: Burns \& Oates.

Anselin L, Varga A and Acs Z (1997) Local geographic spillovers between university research and high technology innovations. Journal of Urban Economics 42(3): $422-448$.

Asheim B, Coenen L, Moodysson J and Vang J (2005) Regional innovation system policy: a knowledge-based approach. CIRCLE (Centre for Innovation, Research and Competence in the Learning Economy) Working Paper.

Audretsch DB and Feldman MP (1996) R\&D spillovers and the geography of innovation and production The American Economic Review 86(3): 630-640.

Autio E (1998) Evaluation of RTD in regional systems of innovation. European Planning Studies 6(2): 131-140.

Balland PA, Boschma R and Frenken K (2015) Proximity and innovation: from statics to dynamics. Regional Studies 49(6): 907-920.

Balland PA (2012) Proximity and the evolution of collaboration networks: evidence from research and development projects within the global navigation satellite system (GNSs) industry. Regional Studies 46(6): 741-756.

Bathelt $\mathrm{H}$ and Depner $\mathrm{H}$ (2003) Innovation, institution and region: a commentary on the discussion of national and regional innovation systems. Erdkunde 57: 126-143.

Beckert J (1999) Agency, entrepreneurs, and institutional change: the role of strategic choice and institutionalized practices in organizations. Organization Studies 20(5): $777-799$.

Boschma R (2005) Proximity and innovation: a critical assessment. Regional Studies 39(1): 61-74.

Boschma R and Frenken K (2009) Some notes on institutions in evolutionary economic geography. Economic Geography 85(2): 151-158. 
Bottazzi L and Peri G (2003) Innovation and spillovers in regions: evidence from European patent data. European Economic Review 47(4): 687-710.

Braczyk HJ, Cooke PN and Heidenreich M (1998) Regional Innovation Systems: The Role of Governances in a Globalized World. Hove: Psychology Press.

Breschi S and Malerba F (1997) Sectoral innovation systems: technological regimes, Schumpeterian dynamics, and spatial boundaries. In: Edquist C (ed.) Systems of Innovation: Technologies, Institutions and Organizations. London: Pinter Publishers, 130-156.

Broekel T and Boschma R (2012) Knowledge networks in the Dutch aviation industry: the proximity paradox. Journal of Economic Geography 12(2): 409-433.

Capello R and Caragliu A (2018) Proximities and the intensity of scientific relations: synergies and nonlinearities. International Regional Science Review 41(1): 7-44.

Carlsson B and Jacobsson S (1994) Technological systems and economic policy: the diffusion of factory automation in Sweden. Research Policy 23(3): $235^{-248 .}$

Carlsson B and Jacobsson S (1997) In search of useful public policies - key lessons and issues for policy makers. In: Technological Systems and Industrial Dynamics. Boston, MA: Springer, 299-315.

Carlsson B and Stankiewicz R (1991) On the nature, function and composition of technological systems. Journal of Evolutionary Economics 1(2): 93-118.

Castaneda DI and Toulson P (2021) Is it possible to share tacit knowledge using information and communication technology tools? Global Knowledge, Memory and Communication. E-pub ahead of print, 11 April. DoI: 10.1108/GKMC-07-202O-01O2.

Coenen L, Moodysson J and Asheim BT (2004) Nodes, networks and proximities: on the knowledge dynamics of the Medicon Valley biotech cluster. European Planning Studies 12(7): 1003-1018.

Cooke P (2004) The role of research in regional innovation systems: new models meeting knowledge economy demands. International Journal of Technology Management 28(3-6): 507-533.

Davenport S (2005) Exploring the role of proximity in SME knowledge-acquisition. Research Policy 34(5): 683-701.

Doloreux D (2002) What we should know about regional systems of innovation. Technology in society 24(3): 243-263.

Edquist C (2001) The systems of innovation approach and innovation policy: an account of the state of the art. Paper presented at the D RUID conference, Aalborg, 12-15.

Etzkowitz H (2008) The Triple Helix: University-Industry-Government Innovation in Action. London: Routledge.

Etzkowitz H and Leydesdorff LA (1997) Universities and the Global Knowledge Economy: A Triple Helix of University-Industry-Government Relations. London: Cassell Academic. 
Etzkowitz H and Leydesdorff LA (1995) The triple helix - university-industry government relations: a laboratory for knowledge based economic development. EAssT Review 14(1): 14-19.

Etzkowitz $\mathrm{H}$ and Leydesdorff L (2000) The dynamics of innovation: from national systems and "mode 2 " to a triple helix of university-industry-government relations. Research Policy 29(2): 109-123.

European Commission (2010) Communication from the Commission Europe 2020: A Strategy for Smart, Sustainable and Inclusive Growth. Brussels: Office of the European Union.

Fitjar RD, Huber F and Rodríguez-Pose A (2016) Not too close, not too far: testing the Goldilocks principle of "optimal" distance in innovation networks. Industry and Innovation 23(6): 465-487.

Fornahl D and Brenner T (2003) Cooperation, Networks and Institutions in Regional Innovation Systems. Cheltenham: Edward Elgar Publishing.

Garcia R, Araujo V, Mascarini S, Gomes Dos Santos E and Costa A (2018) Is cognitive proximity a driver of geographical distance of university-industry collaboration? Area Development and Policy 3(3): 349-367.

Gertler MS (2003) Tacit knowledge and the economic geography of context, or the undefinable tacitness of being (there). Journal of Economic Geography 3(1): 75-99.

Granovetter M (1985) Economic action and social structure: the problem of embeddedness. American Journal of Sociology 91(3): 481-510.

Hansen T (2015) Substitution or overlap? The relations between geographical and nonspatial proximity dimensions in collaborative innovation projects. Regional Studies 49(10): 1672-1684.

Howells JR (2002) Tacit knowledge, innovation and economic geography. Urban Studies 39(5-6): 871-884.

Hussler C (2004) Culture and knowledge spillovers in Europe: new perspectives for innovation and convergence policies? Economics of Innovation and New Technology $13(6): 523-541$.

Katz C (1994) Playing the field: questions of fieldwork in geography. The Professional Geographer 46(1): 67-72.

Kirat T and Lung Y (1999) Innovation and proximity: territories as loci of collective learning processes. European Urban and Regional Studies 6(1): 27-38.

Kiryushin P, Mulloth B and Iakovleva T (2013) Developing cross-border regional innovation systems with clean technology entrepreneurship: the case of Øresund. International Journal of Innovation and Regional Development 5(2): 179-195.

Knoben J and Oerlemans LA (2006) Proximity and inter-organizational collaboration: a literature review. International Journal of Management Reviews 8(2): 71-89.

Koschatzky K (2000) A river is a river-cross-border networking between Baden and Alsace. European Planning Studies 8(4): 429-449. 
Lagendijk A and Lorentzen A (2007) Proximity, knowledge and innovation in peripheral regions. On the intersection between geographical and organizational proximity. European Planning Studies 15(4): 457-466.

Lagendijk A and Oinas P (2005) Proximity, Distance and Diversity: Issues on Economic Interaction and Local Development. Aldershot: Ashgate.

Lander B (2015) Proximity at a distance: the role of institutional and geographical proximities in Vancouver's infection and immunity research collaborations. Industry and Innovation 22(7): 575-596.

Lawson C and Lorenz E (1999) Collective learning, tacit knowledge and regional innovative capacity. Regional Studies 33(4):305-317.

Lundquist KJ and Trippl M (2013) Distance, proximity and types of cross-border innovation systems: a conceptual analysis. Regional Studies 47(3): 450-46o.

Lundvall BA (1992) National Systems of Innovation: An Analytical Framework. London: Pinter.

Makkonen T and Rohde S (2016) Cross-border regional innovation systems: conceptual backgrounds, empirical evidence and policy implications. European Planning Studies 24(9): 1623-1642.

Makkonen T, Weidenfeld A and Williams AM (2017) Cross-border regional innovation system integration: an analytical framework. Tijdschrift voor economische en sociale geografie 108(6): 805-820.

Malerba F (2002) Sectoral systems of innovation and production. Research Policy 31(2): $247-264$.

Malmberg A and Maskell P (2006) Localized learning revisited. Growth and Change 37(1): 1-18.

Maskell P and Malmberg A (1999) Localised learning and industrial competitiveness. Cambridge Journal of Economics 23(2): 167-185.

Mastrom Jr JP (2013) Using social media tools to enhance tacit knowledge sharing within the USMC. Naval Postgraduate School Monterey, CA.

Mattes J (2012) Dimensions of proximity and knowledge bases: innovation between spatial and non-spatial factors. Regional Studies 46(8): 1085-1099.

Mattessich PW, Murray-Close M and Monsey BR (2001) Collaboration: What Makes it Work. St. Paul, MN: Fieldstone Alliance.

Metcalfe S (1994) The economic foundations of technology policy: equilibrium and evolutionary perspectives. In: Dodgson M and Rothwell R (eds) The Handbook of Industrial Innovation. Cheltenham: Edward Elgar, 409-512.

Moodysson J and Zukauskaite E (2014) Institutional conditions and innovation systems: on the impact of regional policy on firms in different sectors. Regional Studies 48(1): 127-138.

Moulaert F and Sekia F (2003) Territorial innovation models: a critical survey. Regional Studies 37(3): 289-302. 
Mowery DC and Nelson RR (1999) Sources of Industrial Leadership: Studies of Seven Industries. Cambridge: Cambridge University Press.

Mytelka LK (2000) Local systems of innovation in a globalized world economy. Industry and Innovation 7(1): 15-32.

Nelson RR (1993) National Innovation Systems: A Comparative Analysis. Oxford: Oxford University Press (on demand).

Niosi J, Saviotti P, Bellon B and Crow M (1993) National systems of innovation: in search of a workable concept. Technology in Society 15(2): 207-227.

Nooteboom B (200o) Learning by interaction: absorptive capacity, cognitive distance and governance. Journal of Management and Governance 4(1-2): 69-92.

North DC (1990) Institutions, Institutional Change and Economic Performance. Cambridge: Cambridge University Press.

OECD (1999) Boosting Innovation: The Cluster Approach. Paris: OECD Publishing.

oECD (2013) Regions and Innovation: Collaborating Across Borders. Paris: OECD Publishing.

Paci R, Marrocu E and Usai S (2014) The complementary effects of proximity dimensions on knowledge spillovers. Spatial Economic Analysis 9(1): 9-30.

Pan RK, Kaski K and Fortunato S (2012) World citation and collaboration networks: uncovering the role of geography in science. Scientific Reports 2: 902.

Perkmann M (2003) Cross-Border Regions in Europe: Significance and Drivers of Regional Cross-Border Co-Operation. European Urban and Regional Studies 10: 153-171.

Polanyi K (1944) The Great Transformation: The Political and Economic Origins of Our Time. Boston: Beacon Press.

Porter ME (1990) Competitive advantage of nations. Harvard Business Review 1(1): 14.

Porter ME (2000) Location, competition, and economic development: local clusters in a global economy. Economic Development Quarterly 14(1): 15-34.

Rallet A and Torre A (1999) Is geographical proximity necessary in the innovation networks in the era of global economy? GeoJournal 49(4): 373-380.

Ranga M (2012) The "grand challenges" of the triple helix. United Nations Economic Commission for Europe. KBD Newsletter, November, 1-2.

Ranga M and Etzkowitz H (2013) Triple helix systems: an analytical framework for innovation policy and practice in the knowledge society. Industry and Higher Education 27(4): 237-262.

Scott WR (2001) Institutions and Organizations. Thousand Oaks, CA: Sage.

Storper M (1997) The regional world: territorial development in a global economy. Guilford press.

Storper M and Venables AJ (2004) Buzz: face-to-face contact and the urban economy. Journal of Economic Geography 4(4): 351-370. 
Torre A and Rallet A (2005) Proximity and localization. Regional Studies 39(1): 47-59. Trippl M (2010) Developing cross-border regional innovation systems: key factors and challenges. Tijdschrift voor economische en sociale geografie 101(2): 150-16o.

Trippl M (2012) Innovation networks in a cross-border context: the case of Vienna. In: Van Geenhuizen M and Nijkamp P (eds) Creative Knowledge Cities: Myths, Visions and Realities. Cheltenham: Edward Elgar Publishing, 273.

UNEP (2006) Manualon Compliance with andEnforcementof MultilateralEnvironmental Agreements. United Nation Environmental Program.

van den Broek, JOS and Smulders H (2014) Institutional gaps in cross-border regional innovation systems: the horticultural industry in Venlo-Lower Rhine. In: Rutten R, Benneworth P, Irawati D and Boekema F (eds) The Social Dynamics of Innovation Networks. London: Routledge, 183-202.

Weidenfeld A (2013) Tourism and cross border regional innovation systems. Annals of Tourism Research 42(July): 191-213.

Zeller C (2004) North Atlantic innovative relations of Swiss pharmaceuticals and the proximities with regional biotech arenas. Economic Geography 8o(1): 83-111. 